\title{
APPAREL ATTRIBUTES: A REINFORCER ON IMPULSE BUYING BEHAVIOR OF COLLEGE STUDENTS IN BANGALORE CITY
}

\author{
*C. NAGADEEPA \\ **PUSHPA A
}

\begin{abstract}
Apparel is one of the basic human needs apart from food, water and shelter. In India, Apparel is the second largest retail industry after IT industry and also second largest foreign exchange earner for the country. This paper attempts to find out the relationship between the product attributes and impulse buying behavior with reference to College students in Bangalore City. And also the focus is to identify the different temperamental background of impulse buying behavior among male and female students. Trendy, Fashionable, Colour scheme, Quality, brand etc are the various factors related to product attributes examined. Convenience sampling method was used to collect the data, structured questionnaires were distributed to 250 respondents. The data is analyzed using SPSS, Chi-square test is used to find out the relationship between the variables.
\end{abstract}

Keywords : Apparel industry, Generation Y, Impulse buying behavior, Productattributes

\section{INTRODUCTION}

"Window shopping" is the growing culture in India. The substantial increase in disposable income, spending capacity is the reasons for growing window shopping culture. India is in the 4th place, in terms of purchasing power parity (PPP) economy, after USA, China and Japan. To overcome the stress, tension, boredom and to relax people tend to go for an outing. But due the growing mall culture people are attracted going out for a window shopping. Most of the time window shopping triggers impulse buying. Many people fall victim to the last-minute impulse purchase. In fact, 90 percent of shoppers buy items not on their shopping list, indicating that the impulse buy is alive and well, according to a new survey. The phenomenon of impulse buying is affecting the people around the world especially the metro cities. The act of unplanned buying is called impulse buying. It arises spontaneously and urges the consumer to "BUY NOW" and "all of a sudden" being hit with urges to buy something."

The Gen Y customers aged 18 to 25 plays an important role for the Indian marketers as they constitute an important part of the target customers. They are the key customers in the terms of magnitude and spending capacity. The census report that about $54 \%$ of the population i.e. 540 million are in the age of 25 and $45 \%$ are below the age 19 yrs. Their disposal income is increasing day by day as they get more pocket

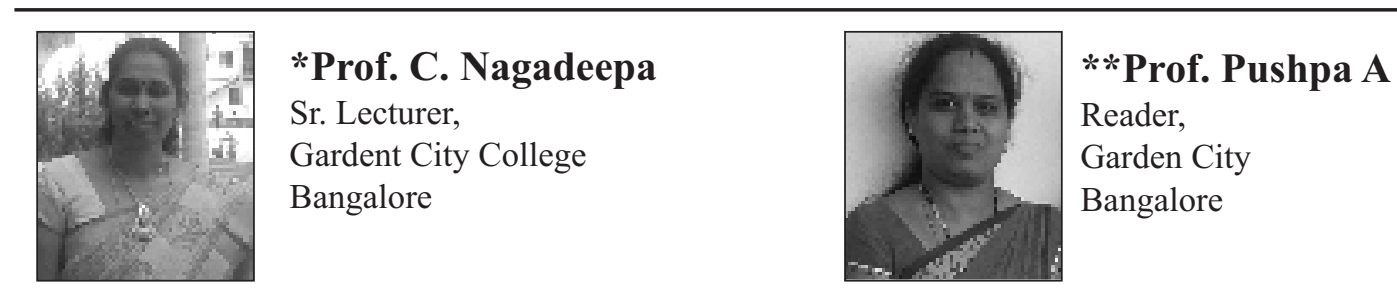


money from parents and also capable of earning from part-time jobs. Also they are very much interested in shopping trendy Apparels, accessories, beauty products, also find these items to be important. Apparels reflect the lifestyle and also the social and economic status of the Gen Y customers.

There are several internal and external factors which influence the impulse buying behavior of the customers such as the store environment, customer psychology, promotional activities etc. According to Gagliano, K.B., Hathcote, the customer's age, gender, income and ethnicity are considered as important factors which has the ability to shape customer's expectation and purchasing. Marketer do lot of exercise in motivated a customer to make purchases impulsively. Some of the strategies taken up are store incentives, sales promotional activities and differentiations in product etc. The present study tends to evaluate the contribution of apparel product attributes towards the consumer's impulse buying behavior. According to Zhang et al, by analyzing the relation between product attributes and consumer's attitude, apparel marketers can understand the consumer's need. It is important for the marketer to serve the customers and increase their sale. Customers can take away this feel only when the apparel marketer makes an attempt in providing apparels which are trendy and fashionable designs, introduce new and unique designs, pattern and variety in apparels, presenting it attractively, unique appearance, colour scheme, patterns etc.

Apparel products are comprised with many physical characteristics, which are perceived differently by the consumers. The preferences for the apparel is influenced by the product attributes such as brand familiarity, product composition factor, WOW factor, quality, value for the price etc. Apparel product composition refers to the factors like fit, texture, durability, shape, size, colour, texture, pattern etc. Product WOW factor refers to the psychological experience felt by the customer which makes the customer feel excited or impressed or surprised at the sight of the product relating to the product quality or feature of the product or presentation of the product. This experience is created by the marketer only when he can differentiate his product from other retailers.

\section{LITERATURE REVIEW}

Thomas \& Sekar, (2008) developed apparel buying behavior model with five important dimensions, namely consumer characteristics, reference groups, store attributes, promotion and product attributes. Based on the various consumer behaviour research studies and also on the opinion of various experts from the industry and academic institutions, these dimensions are created. Product attributes are the product features like style/design, quality, price, brand, fit etc.

Kwan et al (2004) in his study classified the product attributes into two major categories; intrinsic and extrinsic related to consumer's clothing purchase decision. Further the extrinsic criteria was categorized into Product composition, quality, product performance and price.

According to Jones et. all. (2003), he proved that product characteristics can also influence consumer's impulsive buying behavior. Beatty, S. E. and Ferrell M. E. (1998) in his research stated that the product characteristics such as the appearance of products in the retail environment 
and some of the product features such as durability have an impact on consumer impulse buying behavior.

According to Babin, B.J., Darden, W.R. and Griffin, M. (1994), categorized the product into two types with different applications. The first category belongs to hedonic products which are mainly used for their hedonic advantages and the second category belongs to functional products which are mainly used for practical values. Impulse purchasing generally falls under the category of hedonic products which are not mostly supposed to accomplish practical needs because Impulse purchase happens while a customer is motivated by sudden and influential incentives to purchase a product.

\section{OBJECTIVE OF THE STUDY:}

In the booming Apparel retail market, marketers operate in competitive environment facing challenges in changing customer needs, types of retailing and technology, it is inevitable for the marketer to learn how to retain the market share as well as to increase the sales. This research paper focuses on to explore the different aspect that have impact on college student's impulse buying behavior in apparel retail sector in Bangalore. The following objectives were set to prove the above said statement:

- To explore the impact of different product attributes on college students buying behavior.

- To know the buying behavior exhibited by the Gen $\mathrm{Y}$ customers in purchase of apparel.

- To evaluate the relationship of various product dimension / attributes on consumer impulse buying behavior.

\section{RESEARCH HYPOTHESIS}

For this research, the following hypotheses are developed:

H1: Product attributes has a strong association with the impulse buying behavior of the shopper with reference to apparel purchases in organized retail stores.

H1a: Product Quality has a significant impact on consumers' impulse buying behavior towards apparel.

H1b: Brand popularity has a significant impact on consumers' impulse buying behavior towards apparel.

H1c: Product composition has a significant relationship on consumers' impulse buying behavior towards apparel.

H1d: Value for the Price has a significant impact on consumers' impulse buying behavior towards apparel.

H1e: Product WOW factor has a significant impact on consumers' impulse buying behavior towards apparel.

\section{RESEARCH METHODOLOGY}

This present study has been conducted to find out the perception, views and attitude of consumers towards various attributes of apparel product. The study restricts the attributes to Product quality, Brand popularity, product composition, value for price, product WOW factors. The study is administered with the data collected with the help of a structured questionnaire from the young apparel shoppers of 5 different malls in Bangalore City. From each of the five malls, 50 responses were obtained, for a sample size of 250 . 
Questionnaires were distributed to 260 respondents. A total of 250 fully filled questionnaires were considered for the research and rest of the questionnaire are not included due to incomplete response. The questionnaire consists of two parts. The first part consists of demographic data age, gender, disposable income and core field of study of respondents. The second part of the questionnaire consists of questions measuring the impact of product attributes of apparels on impulse buying behavior of college students, 16 questions were developed using the previous studies. Questions mainly addressed on the Product quality, Brand popularity, Product composition, Value for the price and Product WOW factor. For product wow factor on apparel impulse buying such as appearance, trendy, fashion and unique design, a total of five items were drawn from the literature (Susana Azevedo et al. 2008). Six items were adapted from the literature to measure the impulsivity of apparel buying (Kwan C.Y. et al. 2004) encompassing both product composition and quality. Three items measuring brand familiarity purchase scale was adapted from the previous study (Shailesh Kumar Kaushal, 2013) and two items measuring the value for the price is adapted from the previous literature (EunJoo Park, 2011). Five items to measure impulse buying behavior was framed by modifying the impulsivity scale (Rook and Fisher, 1995).

The responses to each variable was measured using a 5-point Likert scale, ranging from strongly disagree $=1$ to strongly agree $=5$. After collecting and scrutinizing the questionnaires, the data of completed questionnaires were coded and then entered into SPSS tool for analysis.

The reliability of the scale is assessed using Cronbach's Alpha. This is applied to calculate the internal coordination of the measurement instruments. The overall Cronbach's alpha is 0.79 , which is more than the standard value 0.7 . Further, factor analysis was used to categories the variables into 5 factors and are termed as Product quality, Brand popularity, Product composition, Value for the price and Product WOW factor.

\begin{tabular}{|l|l|}
\hline Item & Measuring factor \\
\hline Product Quality & Quality of the apparel \\
\hline Brand Popularity & Branded apparel, Brand popularity, Favorite brand \\
\hline Product Composition & $\begin{array}{l}\text { Colour choice and attractive colour, durability, mix and match } \\
\text { facility, fitting and size }\end{array}$ \\
\hline Product Wow factor & Appearance, trendy, fashion, variety and unique design \\
\hline Value for the Price & Adequate price for the apparel \\
\hline
\end{tabular}




\section{FINDINGS AND DISCUSSION}

From the demographic profiles of the respondents, it is understood that $37 \%$ of the respondents are in the age group of 18 to 20 years, $63 \%$ are above 22 years. $33 \%$ of the respondents are students from Arts and Management, $23 \%$ of them from Engineering, $20 \%$ of them are from medical. Majority of the respondents are female i.e., 70\%. The monthly income of the $28 \%$ respondents is less than $15,000,39 \%$ is in the range of 16,000 and 30,000 and the rest is getting above 30,000 .

The reliability of the scale is assessed using Cronbach's Alpha. This is applied to calculate the internal coordination of the measurement instruments. The overall Cronbach's alpha is 0.79 , which is more than the standard value 0.7 . Using factor analysis, these data are classified into 5 factors which are named as Product quality, Brand popularity, Product composition, Value for the price and Product WOW factor.

Table 1 shows the result of chi-square test. Hence, the analysis concludes that there is a significant relationship between product composition and consumer impulse buying behavior and is also influenced by colour choice, attractive colour combinations, size/fit, durability and fabric $(\mathrm{p}<0.05$ i.e. 0.021$)$. Hence, it is proved that the proposed hypothesis $\mathrm{H} 1 \mathrm{c}$ is accepted.

Followed by product composition the other product attribute that has a positive impact on consumer's impulse buying behavior is the Product WOW factor which includes new fashion, trendy, unique design, attractive appearance and variety etc., The test reveals that the $p=0.027$, which is less than $p<0.05$. Hence, H1e is accepted.

Table 1: Chi-Square Test

\begin{tabular}{|l|c|c|c|c|c|c|c|}
\hline \multicolumn{1}{|c|}{$\begin{array}{c}\text { Cross tabulation } \\
\text { Variables }\end{array}$} & SA & A & NAND & D & SD & $\begin{array}{c}\text { Pearson } \\
\text { Chi-square }\end{array}$ & Result \\
\hline $\begin{array}{l}\text { Impulse buying behavior / } \\
\text { Brand familiarity }\end{array}$ & 85 & 55 & 56 & 32 & 22 & 0.601 & Insignificant \\
\hline $\begin{array}{l}\text { Impulse buying behavior / } \\
\text { Product composition }\end{array}$ & 88 & 99 & 30 & 18 & 15 & 0.021 & Significant \\
\hline $\begin{array}{l}\text { Impulse buying behavior / } \\
\text { WOW factor }\end{array}$ & 102 & 97 & 16 & 23 & 12 & 0.027 & Significant \\
\hline $\begin{array}{l}\text { Impulse buying behavior / } \\
\text { Quality }\end{array}$ & 30 & 75 & 90 & 40 & 15 & 0.318 & Insignificant \\
\hline $\begin{array}{l}\text { Impulse buying behavior / } \\
\text { Value for the price }\end{array}$ & 77 & 78 & 49 & 32 & 14 & 0.69 & Insignificant \\
\hline
\end{tabular}

SA-Strongly Agree, A-Agree, NAND-Neither agree nor disagree, D-Disagree, SD-Strongly disagree 
Further, the research found that there is no significant relationship between consumer impulse buying behavior and other attributes of product such as quality, brand popularity and value for the price considered in the study as the $p>0.05$. Hence, the Hypothesis H1a, H1b and $\mathrm{H} 1 \mathrm{~d}$ are rejected.

\section{CONCLUSION:}

Window shopping creates an opportunity for the apparel marketers to attract the customers and enhance their sales. Hence, it is very important to understand the consumer psyche and proceed accordingly. The study examined the influence of product attributes and college students' behavior towards the apparel impulse buying decision. The study revealed that among the product attributes, the product composition and WOW factor are the main dimensions of apparel impulse buying behavior. This shows that the apparel marketers should give more importance to these attributes to attract the customers. The apparel marketer should concentrate on attribute like fashion, trendy and appearance of the apparels.

\section{Limitations and Suggestions for future Research}

The research has few limitations which must be acknowledged. The main limitation in this study is it is restricted only to a part of Bangalore City with a small sample size and limited market segment.

Due to these reasons the result of the present study cannot be generalized universally. Further study can be conducted on other segments of customers. Another limitation is that the study has considered only the apparel sector; study can be extended to other product lines.

The data is based on the opinion of the respondents and it may change from time to time. This study has not considered other external factors like economy, technology etc. and these factors may be taken up for future research not included in the model and may be tested.

\section{REFERENCES:}

- Aaker, D. J., \& Joachimsthaler, E.(2000). The Brand Relationship spectrum: The key to the Brand Architecture Challenge. California Management Review USA, 54, 8-23.

- Babin, B.J., Darden, W.R., \& Griffin, M. (1994), Work and/or Fun: Measuring Hedonic and Utilitarian Shopping, Journal of Consumer Research, 20, 644-656.

Balanagagurunathan, K.,\&Krishnakumar, M.(2013). Factors influencing Apparel Buying Behaviour in India: A measurement model. Paripex - Indian journal of research, 2(3), 44-57.

Bhattacharya, C.B., \&Sen, S. (2003). Consumer-Company Identification: A Framework for understanding consumers' relationships with companies. Journal of marketing, American marketing association,67, 76- 88.

- Beatty, S. E., \& Ferrell, M. E. (1998), Impulsive Buying: Modeling Its Precursors, Journal of Retailing, 74(2),169-191.

- Dolekoglu, C.O., Albayrak, M., Kara, A.,\&Keskin, G. (2008). Analysis of consumer perceptions and preferences of store brands versus national brands: An exploratory study in an emerging market. Journal of euro-marketing, 17(2), 109-125.

Dickson, M.A., Lennon, S. J., Montalto, C.P., Shen, D., \&Zhang, L. (2004). 
Chinese consumer market segments for Foreign apparel products.Journal of Consumer Marketing, 21(5), 301-317.

- EunJoo Park, EunYound Kim, Venessa Martin Funches \& William Foxx. (2012). Apparel product attributes, web browsing, and e-impulse buying on shopping websites. Elsevier Journal of Business $\mathrm{R}$ e s e a r c h, 65 ( 11 ) , 1583 1589.doi:10.1016/j.jbusres.2011.02.43.

- Gagliano, K.B.,\&Hathcote, J.(1994). Customer Expectations and Perceptions of service quality in retail apparel specialty stores.Journal of Services Marketing, 8(1), $60-69$.

- Jin \& Kang.(2010). Face or Subjective Normfl Chinese College Students Purchase Behaviors towards Foreign Brand Jeans, Clothing and Textile Research Journal,28(3), p 218-233.

- Jones, Michael, A., Kristy Reynolds, E., SeungoogWeun, \& Sharon E. Beatty. (2003). The product-specific nature of impulse buying tendency. Journal of Business Research, 56(7), 505-11.

- $\quad$ Kim, Y., Kim, E.Y, \& Kumar, S. (2003). Testing the behavioral intentions model of online shopping for clothing. Clothing and textile research journal, 21(1), 32-40.
Krishna, C. V.(2011). Determinants of consumer buying behavior: An empirical study of Private Label Brands in Apparel Retail. Vilakshan: The XIMB Journal of Management, 8 (2),43- 56.

Kwan. C.Y, Yeung, K.W, \& Au, K.F. (2004), Decision Making Behavior Towards Casual Wear Buying: A Study of Young Consumers in Mainland China. Journal of Management and World Business Research,1, 1-10.

Rook, D.W., \& Fisher, R.J. (1995). Normative influence on impulsive buying behavior. Journal of consumer Research, 22, 205-313.

Shailesh Kumar Kaushal (2013). The importance of apparel product attributes for teenaged buyers. NMIMS Management Review, 23, 45-64.

- Susana Azevedo, \& Madalena Pereira (2008). Consumer buying behavior in Fashion Retailing: Empirical evidences. Retrieved from http://mpra.ub.unimuenchen.de/11908/MRPApaper.

Annexure:

Reliability Statistics

\begin{tabular}{|r|c|}
\hline Cronbach's Alpha & N of Items \\
\hline .790 & 21 \\
\hline
\end{tabular}

\section{KMO and Bartlett's Test}

\begin{tabular}{|l|l|c|}
\hline & $\begin{array}{l}\text { Kaiser-Meyer-Olkin Measure of Sampling } \\
\text { Adequacy. }\end{array}$ & .602 \\
\hline \multirow{3}{*}{ Bartlett's Test of Sphericity } & Approx. Chi-Square & 168.802 \\
\cline { 2 - 3 } & Df & 91 \\
\cline { 2 - 3 } & Sig. & .000 \\
\hline
\end{tabular}


Rotated Component Matrixa

\begin{tabular}{|c|c|c|c|c|c|}
\hline & \multicolumn{5}{|c|}{ Component } \\
\hline & 1 & 2 & 3 & 4 & 5 \\
\hline Brand popularity & & & & & \\
\hline The branded apparel tempts me to buy & .662 & & & & \\
\hline $\begin{array}{l}\text { Design popularity will attract my attention and induce my } \\
\text { unplanned purchase }\end{array}$ & .387 & & & & \\
\hline When I see my favourite brand immediately I buy it. & .778 & & & & \\
\hline $\begin{array}{l}\text { Quality: } \\
\text { I buy spontaneously when I see best quality apparel }\end{array}$ & & .459 & & & \\
\hline $\begin{array}{l}\text { Value for the price } \\
\text { If I find the apparel with the best value for money, } \\
\text { immediately I buy it } \\
\text { The reasonable product price tempts me buy immediately }\end{array}$ & & & .803 & & \\
\hline Product Composition: & & & & & \\
\hline Colour choice make me to buy spontaneously & & & & .765 & \\
\hline Attractive colour combination of the apparel tends me to buy & & & & .744 & \\
\hline The option of Mix and Match triggers me to buy & & & & .108 & \\
\hline The durability of fabric tempts me to buy & & & & .655 & \\
\hline Proper fitting of the apparel tempts me to buy & & & & .563 & \\
\hline Product WOW factor & & & & & \\
\hline The appearance of the product triggers me to buy & & & & & .719 \\
\hline I buy spontaneously when I see trendy and fashionable apparel & & & & & .687 \\
\hline $\begin{array}{l}\text { Design popularity will attract my attention and induce my } \\
\text { unplanned purchase }\end{array}$ & & & & & .630 \\
\hline When I see the varieties of apparel I tend to buy immediately & & & & & .732 \\
\hline I really enjoy trying different apparel & & & & & .627 \\
\hline
\end{tabular}

Extraction Method: Principal Component Analysis.

Rotation Method: Varimax with Kaiser Normalization.

a. Rotation converged in 16 iterations. 
Item Statistics

\begin{tabular}{|c|c|c|c|}
\hline & Mean & Std. Deviation & $\mathrm{N}$ \\
\hline $\begin{array}{l}\text { The branded apparel tempts } \\
\text { me to buy }\end{array}$ & 3.50 & 1.407 & 250 \\
\hline $\begin{array}{l}\text { Design popularity will attract my } \\
\text { attention and induce my } \\
\text { unplanned purchase }\end{array}$ & 3.29 & 1.054 & 250 \\
\hline $\begin{array}{l}\text { When I see my favourite brand } \\
\text { immediately I buy it. }\end{array}$ & 3.79 & 1.226 & 250 \\
\hline $\begin{array}{l}\text { I buy spontaneously when I see } \\
\text { best quality apparel }\end{array}$ & 3.56 & 1.259 & 250 \\
\hline $\begin{array}{l}\text { If I find the apparel with the best } \\
\text { value for money, immediately I } \\
\text { buy it }\end{array}$ & 3.38 & 1.255 & 250 \\
\hline $\begin{array}{l}\text { The reasonable product price } \\
\text { tempts me buy immediately }\end{array}$ & 3.35 & 1.467 & 250 \\
\hline $\begin{array}{l}\text { Colour choice make me to buy } \\
\text { spontaneously }\end{array}$ & 2.96 & 1.414 & 250 \\
\hline $\begin{array}{l}\text { Attractive colour combination of } \\
\text { the apparel tends me to buy }\end{array}$ & 2.90 & 1.209 & 250 \\
\hline $\begin{array}{l}\text { The option of Mix and Match } \\
\text { triggers me to buy }\end{array}$ & 3.33 & 1.248 & 250 \\
\hline $\begin{array}{l}\text { The durability of fabric tempts } \\
\text { me to buy }\end{array}$ & 3.52 & 1.229 & 250 \\
\hline $\begin{array}{l}\text { Proper fitting of the apparel } \\
\text { tempts me to buy }\end{array}$ & 3.25 & 1.235 & 250 \\
\hline $\begin{array}{l}\text { The appearance of the product } \\
\text { triggers me to buy }\end{array}$ & 3.12 & 1.278 & 250 \\
\hline $\begin{array}{l}\text { I buy spontaneously when I see } \\
\text { trendy and fashionable apparel }\end{array}$ & 3.38 & 1.430 & 250 \\
\hline
\end{tabular}

